\author{
Dr. sc. Miodrag Mićović, profesor \\ Pravnog fakulteta Univerziteta u Kragujevcu
}

\title{
PROFESIONALNI SPORTSKI KLUB
}

\author{
UDK: $796 / 799: 347.7$. \\ Primljeno: 1. 10. 2016. \\ Izvorni znanstveni rad
}

\begin{abstract}
Povodom organizacije profesionalnih klubova primenjuju se dva modela. Jedan, povodom koga klubovi imaju slobodu izbora organizacionog oblika (udruženje ili privredno društvo) u kome će obavljati sportske aktivnosti. Drugi, prema kome se klubovi obavezno organizuju u obliku privrednog društva, u nekoj od formi društva kapitala, s tim što to mogu biti i specijalizovane sportske forme. Na osnivanje i delovanje sportskih društava, kao sui generis trgovačka društva, primenjuje se više posebnih pravila koja se tiču: uslova za osnivanje klubova; uslova za učešće u stručnim i upravljačkim organima; zabrane višestruke svojine u sportskim klubovima, odnosno zabrane članstva; raspodele neto dobiti; nadzora nad radom klubova; državne pomoći (subvencije) klubovima.
\end{abstract}

Ključne reči: sportski klub, privredno društvo, udruženje, forma, sportska aktivnost

\section{UVODNE NAPOMENE}

Istorijski posmatrano, razvoj sporta pratili su odgovarajući organizacioni oblici. Od početka pa sve do danas, sport, za najveći broj poklonika sportskih aktivnosti, predstavlja sredstvo razonode, unapređenja fizičkog i mentalnog zdravlja, zbog čega su brojne sportske organizacije nastajale prvenstveno kao udruženja građana. Ipak, sa profesionalizacijom i komercijalizacijom sporta, menjaju se shvatanja o pravnim oblicima obavljanja sportske delatnosti. ${ }^{1}$ Sportske organizacije počinju da deluju u nekom od oblika privrednih društava objedinjujući, po pravilu, lica koja se profesionalno bave sportom u vidu zanimanja, a ne radi razonode, koja se takmiče za novac, i one koji investiraju radi sticanja dobiti. ${ }^{2}$ Formira se stav da sportska privredna društva doprinose, $\mathrm{s}$ jedne strane, da se aktivnosti profesionalnih klubova odvijaju na transparentan način, i, s druge strane, privlačenju investicija u sport zbog moguće zarade. ${ }^{3}$

1 O tome: Ivkošić, M., Ceronja, P., „Pravni modeli provođenja postupka obveznog preoblikovanja športskog kluba-udruge u športsko dioničko društvo“, Zbornik PFZ, br. 1/09, str. 127.

2 Prvi profesionalni klub, Sinsinati Red Stokins, osnovan je u SAD-u 1863. godine. Igrači ovog bejzbol kluba plaćani su $930 \$$ godišnje, kada je prosečna godišnja plata u SAD-u iznosila $170 \$$. U Severnoj Americi je osnovana i prva profesionalna liga - Nacionalna liga 1876. godine. O ovome: Nebojša Komnenić, Volonterstvo u sportu, Beograd, 2009., str. 12.

3 Buy, F. i dr., Droit du sport, Paris, 2009., str. 263. 
Način regulisanja sporta, uključujući osnivanje i aktivnosti profesionalnih klubova zavisi od toga da li je prihvaćen intervencionistički ili neintervencionistički model uređenja sporta. Intervencionistički model uređenja sporta ${ }^{4}$ znači da je u konkretnoj državi najznačajniji deo sportskog sistema uređen pravnim normama koje su sadržane u zakonu kojim se uređuju sportske aktivnosti. ${ }^{5}$ Za razliku od toga, u slučaju neintervencionističkog modela, pravne norme kojima se uređuje sport ne nalaze se u okviru posebnog zakonskog teksta, već su deo propisa koji uređuju obavljanje nekih drugih delatnosti (propisi o socijalnoj i zdravstvenoj zaštiti, o udruženjima građana). ${ }^{6}$

Povodom osnivanja profesionalnih klubova u uporednom pravu ne postoji jedinstveno rešenje ko i pod kojim uslovima može ili mora da osnuje klub. U ovom radu će biti izloženi postojeći modeli osnivanja profesionalnih klubova, pravne forme u okviru kojih mogu da obavljaju sportske aktivnosti i delatnost, specifična pravila koja se primenjuju na osnivanje i rad profesionalnih sportskih klubova.

\section{ORGANIZACIONI OBLICI I FORME PROFESIONALNOG SPORTSKOG KLUBA}

U osnovi, danas se razlikuju dva organizaciona oblika preko kojih klubovi učestvuju u sportskom takmičenju. To su: sportsko udruženje i sportsko privredno

4 U teoriji se navodi da se intervencionističkim pristupom šalje jasna poruka da je sport društvena delatnost koja uživa zaštitu pravnog poretka i oličava mnoge društvene vrednosti, da se na taj način diže nivo pravne sigurnosti jer oni na koje se zakon odnosi mogu lakše da sagledaju svoja prava i obaveze. Kao primer država koje primenjuju intervencionistički model uređenja sporta navode se Srbija, Francuska, Italija, Hrvatska, Španija, Mađarska. O tome: Šuput, D., „Zakonsko uređivanje sporta u evropskim državama“, Strani pravni život, br. 3/09, str. 253.

5 Treba naglasiti da se ne mogu sve države koje poseduju poseban zakon koji uređuje sport smatrati državama koje primenjuju intervencionistički model zakonskog uređivanja sporta. Tako Austrija, Finska, Litvanija i Švajcarska imaju zakone koji uređuju sport, ali na takav način da država ne interveniše direktno svojim pravilima u oblasti uspostavljanja sportskih odnosa i osnivanja i rada sportskih organizacija, već propisuje isključivo obaveze državnih organa i službi u pogledu ostvarivanja javnog interesa u oblasti sporta koji se ogleda u stvaranju tehničkih, finansijskih i logističko-administrativnih uslova za upražnjavanje sportskih aktivnosti. O tome: Šuput, D., nav. članak, str. 254.

6 Ovaj model je prihvaćen, na primer, u Velikoj Britaniji, Danskoj, Češkoj. O tome: Šuput, D., nav. članak, str. 255 . 
društvo. ${ }^{78}$ Ako klubovi imaju amaterski status, smatra se poželjnim da sportska organizacija bude organizovana kao udruženje (građana), a ako imaju profesionalni status, ${ }^{9}$ tada bi za njih adekvatan organizacioni oblik bilo sportsko privredno društvo. Međutim, između iznetog stava i onoga što se dešava u praksi postoji izražen raskorak. Prema podacima iz 2014. godine, u Republici Hrvatskoj bilo je 16 profesionalnih klubova, od čega je samo sedam bilo organizovano u formi deoničkih društava; u Republici Srbiji 99 \% klubova je registrovano kao udruženje građana. ${ }^{10}$ Razlog tome treba tražiti, pre svega, u tome što ne postoji zakonska obaveza organizovanja, odnosno preoblikovanja profesionalnih klubova u sportska privredna društva. ${ }^{11}$ Takvo stanje, u pogledu organizacije klubova, slično je i na globalnom planu, što dalje ima za posledicu da se akcije neznatnog broja klubova, iz malog broja zemalja, kotiraju na berzi (prvi klub koji je izašao na berzu, u oktobru 1983. godine, bio je Tottenham Hotspurs). ${ }^{12}$

Uporednopravno posmatrano, povodom organizacije profesionalnih klubova uočljiva su dva modela koja se primenjuju u pojedinim zakonodavstvima: model autonomije, prema kome klub sam bira organizacioni oblik koji mu odgovara i model obaveznog organizovanja profesionalnih klubova u nekoj od formi privrednog društva. ${ }^{13}$

7 Sportska društva se razlikuju od sportskih udruženja po tome što: društvo može da bude osnovano od strane jednog osnivača, a za nastanak udruženja potrebno je da postoji više osnivača (najmanje tri fizička ili pravna lica - čl. 38. st. 1. Zakona o sportu Republike Srbije, Sl. glasnik, br. 10/16; u daljem tekstu ZOS); društva se osnivaju, pre svega, radi ostvarenja ekonomskog cilja u oblasti sporta, a udruženja radi ostvarenja zajedničkog cilja iz oblasti sporta; društva su profitne organizacije, a udruženja neprofitne; unošenje uloga u društvo je obavezno, a u udruženje fakultativno (udruženje sredstva potrebna za ostvarivanje svojih aktivnosti pribavlja putem priloga, članarina, donacija, poklona, subvencija i marketinških, poslovnih i privrednih aktivnosti); u slučaju prestanka društva, imovina koja preostane po izmirenju obaveza raspodeljuje se članovima društva, a kada se radi o udruženju kao primalac njegove imovine statutom se može odrediti samo neprofitna organizacija u oblasti sporta. O tome: Mićović, M., „Sportsko privredno društvo“, Zbornik radova Pravnog fakulteta u Splitu, br. 2/10, str. 278.

8 U pogledu organizacionih oblika postoji drugačije i bolje rešenje kojim se u središte postavlja klub, kao osnovni ili jedan od sportskih oblika organizovanja, koji može imati dvojak status i zavisno od toga organizacioni oblik. Tako, u ZOS-u Bosne i Hercegovine (Sl. glasnik, br. 168/08) se određuje da je osnovni oblik organizovanja u sportu sportski klub, koji može da obavlja aktivnosti amaterski (tada se radi o neprofitnoj organizaciji, koja je organizovana kao udruženje građana) i profesionalno (tada se klub osniva kao privredno društvo) (čl. 17, 18. i 20). Ili, ZOS Crne Gore (Sl. list RCG, br. 36/11, 36/13) u kome je određeno da je jedna od sportskih organizacija sportski klub (čl. 36), koji može imati amaterski (neprofitna organizacija) ili profesionalni status (osniva se kao privredno društvo), zavisno od toga da li se osniva radi sticanja dobiti (čl. 48. i 50).

9 Prema ZOS-u Republike Srbije (S1. glasnik RS, br. 10/16;) profesionalni sportski klub jeste sportska organizacija (klub) koja taj status ima u skladu sa sportskim pravilima ili u kojoj najmanje $50 \%$ registrovanih sportista seniora ima status profesionalnog sportiste u odnosu na broj registrovanih sportista seniora registrovanih kod nadležnog nacionalnog granskog sportskog saveza za takmičarsku sezonu (čl. 3. st. 1. tač. 16). Slična odredba je sadržana i u Zakonu o športu Republike Hrvatske (čl. 24. st. 1; Narodne novine RH, br. 71/06, 150/08 (Uredba), 124/10, 124/11, 86/12, 94/13, 85/15 i 19/16).

10 O tome: Đurđević, N., Mićović, M., Vuković, Z., Ugovori u sportu, Kragujevac, 2014., str. 49; Jelušić, D., Sportsko dioničko društvo, Informator, br. 6310 - 6311 od 30. VIII. 2014. godine, str. 5.

11 Jelušić, D., nav. članak, str. 5.

12 O tome: Đurđević, N., Mićović, M., Vuković, Z., nav. delo, str. 57.

13 Prisutan je i stav da se mogu razlikovati i tri modela organizacije klubova: 1) klub sam bira organizacioni oblik koji mu odgovara (udruženje ili privredno društvo); 2) klub mora da bude organizovan 
Model autonomije je prihvaćen u srpskom ${ }^{14} \mathrm{i}$ hrvatskom pravu. ${ }^{15}$ Takođe, u Grčkoj je dopušteno profesionalnim klubovima da biraju između statusa udruženja i privrednog društva. U Nemačkoj je data mogućnost fudbalskim klubovima, počev od 1998. godine, da se od udruženja preoblikuju u privredno društvo (akcionarsko društvo, društvo sa ograničenom odgovornošću, komanditno društvo na akcije), uz uslov da klub, kao udruženje, u tom društvu ima većinu udela sa pravom glasa (u komanditnom društvu ima položaj komplementara). ${ }^{16}$

Model obaveznog organizovanja profesionalnih klubova u oblik nekog od privrednih društava prihvaćen je u Italiji (od 1982. godine svi klubovi koji imaju profesionalne sportiste moraju da se organizuju kao društvo sa ograničenom odgovornošću ili kao akcionarsko društvo), Poljskoj (u profesionalnom sportu mogu da se takmiče samo klubovi koji su organizovani kao akcionarska društva), ${ }^{17}$ Crnoj Gori (profesionalni sportski klub se osniva kao privredno društvo, s tim što je uvedena obaveza da se amaterski klubovi preoblikuju u profesionalni klub ako imaju zaključene ugovore o radu sa više od $50 \%$ registrovanih sportista u seniorskoj konkurenciji - čl. 50. i 53. ZOS-a), Bosni i Hercegovini (čl. 20. ZOS-a). U ovu grupu zemalja može se svrstati, ali i izdvojiti zbog specifičnih rešenja, Francuska. Prema čl. 122 - 1. st. 1. Zakona o sportu (konsolidovana verzija od 14. jula 2016. godine) sportska udruženja su dužna da osnuju sportsko društvo (osnivanjem društva udruženje nastavlja da vodi amaterski sektor kluba i istovremeno ima status člana društva) ako njihovi prihodi od sportskih događaja prelaze 1.200 .000 evra ili ako naknade koje se isplaćuju sportistima prelaze 800.000 evra. ${ }^{18}$ Radi se o alternativnim kriterijumima, što znači da obaveza konstituisanja sportskog društva postoji i kad je zadovoljen jedan od navedenih kriterijuma (zahvaljući ovom rešenju obavezom formiranja profesionalnog kluba obuhvaćeni su i oni subjekti koji ne organizuju sportske manifestacije profitnog karaktera, kao što su biciklistički klubovi). Cenzusi koji su napred navedeni su niski, što nameće obavezu velikom broju klubova, iz različitih sportskih grana, da se organizuju kao profesionalni klubovi. ${ }^{19}$ Ako

kao društvo kapitala; 3) klub bira organizacioni oblik, s tim što ima mogućnost da svoju prvu ekipu (ili sve ekipe) organizuje kao društvo kapitala u svom vlasništvu ili suvlasnistvu. O tome: Đurđević, N., Mićović, M., Vuković, Z., nav. delo, str. 50.

14 Prema čl. 33. st. 1. ZOS-a radi obavljanja sportskih aktivnosti i sportskih delatnosti sportska organizacija može da se osnuje kao udruženje ili kao sportsko privredno društvo. Uz to, udruženje može da promeni pravni oblik u sportsko privredno društvo donošenjem odluke o organizovanju kao društvo sa ograničenom odgovornošću, čije organe bira jedinica lokalne samouprave (čl. 71). Na ovaj način nastaje neka vrsta sportskog javnog preduzeća, pri čemu je nejasan smisao i opravdanost na ovako izvedene reorganizacije udruženja.

15 Sportski klub, koji ima profesionalni ili amaterski status, može da obavlja sportsku delatnost sudelovanja u sportskom natjecanju, u obliku sportske udruge za natjecanje ili sportskog dioničkog društva (čl. 23. st. 1. Zakona o sportu RH).

16 O tome: Đurđević, N., Mićović, M., Vuković, Z., nav. delo, str. 60.

17 Isto, str. 58

18 Sportsko udruženje može da dobrovoljno konstituiše sportsko društvo i onda kada nisu dostignuti navedeni iznosi - čl. $122-1$, st. 2.

19 Na ovaj način zakonodavac želi da prenese aktivnosti udruženja, koje su slične sa trgovačkim, na organizacionu strukturu koja je prilagođena za njihovo vođenje. Time se postiže veća transparentnost 
udruženja to ne učine u roku od godinu dana, računato od momenta kad je ispunjen jedan od navedenih kriterijuma, biće isključena iz sportskog takmičenja od strane federacije kojoj pripadaju. U svakom slučaju, ako izostane reakcija federacije, sankcija može da bude izrečena od strane suda, a na zahtev svakog zainteresovanog lica. ${ }^{20}$

Kada se radi o formi sportskih društava, uočljivo je da su prihvaćena različita rešenja: prvo, da se mogu osnovati u bilo kojoj od poznatih formi privrednog društva (akcionarsko društvo, društvo sa ograničenom odgovornošću, ortačko društvo i komanditno društvo); drugo, da se mogu osnovati kao društva kapitala (akcionarsko društvo, društvo sa ograničenom odgovornošću); treće, da se mogu osnovati, pored klasičnih formi društva kapitala, u formi sui generis društva, odnosno kao specijalizovano sportsko društvo.

Prvo rešenje je zastupljeno u Crnoj Gori (čl. 50. ZOS-a) i Bosni i Hercegovini (profesionalni sportski klub osniva se kao privredno društvo - čl. 20. st. 1. ZOS-a). Drugo rešenje je zastupljeno u Srbiji (čl. 92. ZOS-a) ${ }^{21}$ i Hrvatskoj (klub deluje u formi deoničkog društva, čiji minimalni osnivački kapital iznosi 500.000 kuna čl. 28. i 30. ZOS-a). ${ }^{22}$ Treće rešenje je zastupljeno u Francuskoj. Zbog posebnih formi i pravila koja su prihvaćena u francuskom ZOS-u biće posebno izložene vrste specijalizovanih sportskih društava.

Francuski ZOS, pored tri klasične forme (društvo sa ograničenom odgovornošću, akcionarsko društvo, društvo sa redovnim akcijama - čl. 122 -2 ZOS-a), definiše tri posebne forme u okviru kojih profesionalni klubovi mogu da deluju (jednopersonalno sportsko preduzeće sa ograničenom odgovornošću, sportsko akcionarsko društvo, profesionalno sportsko akcionarsko društvo).

Jednopersonalno sportsko preduzeće sa ograničenom odgovornošću (uvedeno u pravni sistem Francuske 1999. godine; minimalni osnivački kapital 7.500 evra) predstavlja jedino specijalizovano sportsko društvo koje nema formu akcionarskog društva. Može da bude osnovano od strane sportskog udruženja, koje je jedini član društva. Naziv društva ne može da se razlikuje od naziva udruženja. Dobit koja se ostvari vršenjem sportske delatnosti unosi se u fond rezervi i koristi se isključivo za obavljanje sportskih aktivnosti. Nemogućnost korišćenja dobiti od strane udruženja, uz snošenje rizika koji prate aktivnosti društva, razlog je što je mali broj klubova (rukometni klub Vilerban i fudbalski Ajačio) organizovan u ovoj formi. ${ }^{23}$

Sportsko akcionarsko društvo (société anonyme a objet sportif), uvedeno u pravni sistem Francuske 1984. godine (radi se o zatvorenom društvu koje može

sportskih aktivnosti i bolja finansijska kontrola. O tome: Simon, G., i dr., Droit du sport, Paris, 2012., str. 163.

20 Isto, str. 160.

${ }^{21} \mathrm{U}$ formi akcionarskog ili društva sa ograničenom odgovornošću deluju klubovi u Italiji i Švajcarskoj. O tome: Đurđević, N., Mićović, M., Vuković, Z., nav. delo, str. 58.

22 U formi akcionarskog deluju klubovi u Engleskoj, Španiji i Poljskoj. O tome: Đurđević, N., Mićović, M., Vuković, Z., nav. delo, str. 56. i 59.

23 Amson, Ch., Droit du sport, Paris, 2010., str. 26. 
slobodno da odredi svoj naziv, ima najmanje sedam akcionara i minimalni kapital od 37.000 evra), karakteriše sledeće: nemogućnost raspodele dobiti akcionarima, osim kada se akcije društva kotiraju na berzi ${ }^{24}$ uprava nema pravo na naknadu za rad, osim naknade obrazloženih troškova koji su nastali vezano za poslove koje obavljaju; ukoliko se ne nude javno, akcije su u ograničenom prometu (radi očuvanja „čistote“ sportskih aktivnosti, prenos akcija ne može da se vrši bez saglasnosti nadležnog organa); udruženje osnivača ima kvalitet manjinskog akcionara (ono mora da poseduje najmanje trećinu kapitala i glasova u skupštini društva). Navedena ograničenja predstavljaju kočnicu za prihvatanje ove forme društva, odnosno smetnju za privlačenje investicija (samo 13 klubova funkcioniše u ovoj formi). ${ }^{25}$

Profesionalno sportsko akcionarsko društvo (uvedeno u pravni sistem Francuske 1999. godine, minimalni kapital iznosi 37.000 evra, odnosno 225.000 evra, u slučaju javnog poziva za upis i uplatu akcija) osniva sportsko udruženje, s tim što nije određen limit u pogledu kapitala koji mora da poseduje u društvu (nakon konstituisanja društva akcije koje poseduje udruženje može da prenese na treće lice). Društvo može da raspodeljuje dobit akcionarima, a uprava ima pravo na nadoknadu za svoj rad. Za prenos akcija nije potrebna prethodna saglasnost nadležnog organa, već odobrenje koje dvotrećinskom većinom daje upravni ili nadzorni odbor (odobrenje nije potrebno ako se akcije nude javno). ${ }^{26} \mathrm{U}$ praksi, posmatrano u odnosu na druga specijalizovana društva, najveći broj klubova je konstituisan u ovoj formi. ${ }^{27}$

Nakon konstituisanja nekog od sportskih društava, sportsko udruženje, kao osnivač, i društvo sporazumno uređuju njihove odnose, s tim što sporazum počinje da proizvodi pravno dejstvo od momenta kada ga odobri nadležni organ (smatra se da je odobren ako nadležni organ ne stavi primedbu na sporazum u roku od dva meseca, računato od momenta kada mu je sporazum dostavljen). ${ }^{28}$ Sporazumom se definišu: aktivnosti koje će se odvijati u okviru amaterskog sektora, odnosno one koje će biti deo profesionalnog sektora; modaliteti učešća društva u aktivnostima udruženja (na primer, edukativne aktivnosti, prevencija nasilja u sportu); uslovi pod kojima će koristiti terene i sportske objekte; uslovi pod kojima će društvo moći da koristi oznake udruženja; trajanje sporazuma. ${ }^{29}$

24 Sportsko društvo čije se akcije kotiraju na berzi, pored finansijskih izveštaja i izveštaja o kontroli poslovanja, ima posebnu dužnost da javnost informiše o okolnostima koje mogu da indirektno utiču na cenu akcija, kao što je angažovanje igrača, povrede igrača, odlazak ili dolazak trenera, pozitivan antidoping test nekog igrača. O tome: Buy, F., nav. delo, str. 269.

25 Amson, Ch., nav. delo, str. 25.

26 Buy, F. i dr., nav. delo, str. 284-287.

27 Amson, Ch., nav. delo, str. 26.

28 U teoriji se dovodi u pitanje opravdanost održavanja veze između društva i udruženja. Ističe se da to može da bude kočnica za finansijski razvoj profesionalnog kluba. O tome: Amson, Ch., nav. delo, str. 27.

29 Buy, F. i dr., nav. delo, str. 289-297. 


\section{POSEBNA PRAVNA PRAVILA KOJIMA SE ODREĐUJE OKVIRZA OSNIVANJE I DELOVANJE PROFESIONALNIH KLUBOVA}

Na profesionalne sportske klubove, osnovane u obliku privrednog društva, primenjuju se opšta pravila o privrednim društvima, pod uslovom da u ZOS-u nisu sadržana posebna pravila kojima se regulišu pitanja vezana za osnivanje i poslovanje profesionalnih sportskih klubova. Tih pravila je više, imaju za cilj unapređenje, transparentnost i nadzor nad odvijanjem sportskih aktivnosti, a mogu se razvrstati na ona kojima se uređuje sledeće: 1) uslovi za osnivanje klubova; 2) uslovi za učešće u stručnim i upravljačkim organima; 3) zabrana višestruke svojine u sportskim klubovima, odnosno zabrana članstva; 4) raspodela neto dobiti; 5) nadzor nad radom klubova; 6) državna pomoć (subvencije) klubovima. ${ }^{30}$

1. Uslovi za osnivanje klubova. ${ }^{31}$ - Klub može da obavlja sportske aktivnosti i sportske delatnosti ako ima: 1) angažovane sportiste;32 2) angažovane sportske stručnjake u zavisnosti od vrste delatnosti; 3 ) obezbeđen odgovarajući prostor, odnosno sportske objekte i sportsku opremu; 4) odgovarajuću unutrašnju organizaciju i finansijska sredstva, ako učestvuje u sportskim takmičenjima; 5) osiguranu bezbednost sportista i drugih učesnika pri obavljanju sportskih aktivnosti i delatnosti; 6) odgovarajući broj životinja u sportu u kojem učestvuju životinje (čl. 35. st. 1. ZOS-a Republike Srbije). ${ }^{33}$

2. Uslovi za učešće u stručnim i upravljačkim organima. - Radi se o personalnim uslovima, negativnog karaktera, jer se njima određuje ko ne može da obavlja stručne ili upravljačke poslove u klubu. Smatra se da određena lica zbog svog ranijeg ili aktuelnog delovanja mogu da utiču na sistem takmičenja na način koji je protivan principima sportske etike. Ovakvi uslovi se susreću i kada se radi o nekim drugim privrednim subjektima (berze, banke), koji obavljaju rizične aktivnosti, sa mogućim štetnim posledicama za druge subjekte i ekonomiju u celini. Za razliku od sportskih klubova koji se onivaju u skladu sa normativnim sistemom, za osnivanje drugih subjekata prihvaćen je sistem odobrenja, što znači da nadležni organ ispituje da li su ispunjeni svi uslovi, pa i navedeni, i nakon toga, ako su zadovoljeni svi uslovi, izdaje dozvolu za rad. Dakle, ako se sportske organizacije svrstavaju u grupu

${ }^{30}$ Neka od ovih pravila (navedena pod jedan i dva) primenjuju se i na amaterske klubove osnovane u obliku sportskog udruženja.

31 O tome kada će se smatrati da su ti uslovi zadovoljeni više: Đurđević, N., Mićović, M., Vuković, Z., nav. delo, str. 62-66.

32 Po pravlu se za rad profesionalnih klubova zahteva da imaju sklopljen ugovor o radu (ili ugovor o profesionalnom igranju) sa najmanje $50 \%$ registrovanih sportista - čl. 3. st. 1. tač. 16. ZOS-a Republike Srbije, čl. 24. st. 1. ZOS-a Republike Hrvatske.

33 ZOS Republike Srbije sadrži verovatno najveći broj uslova. U tom pogledu primetne su razlike. Tako, ZOŠ RH sadrži samo dva konkretna uslova (da lice ima pravo korišćenja sportskog objekta i da ima angažovana lica koja su osposobljena za obavljanje stručnih poslova), uz dodatak da je potrebno ispuniti i druge uslove koji su sadržani u pravilima odgovarajućeg nacionalnog sportskog saveza (čl. 21). Ili, u ZOS CG (čl. 41) se određuje da klub može da bude osnovan ako ima određen broj sportista; sportski objekat, odnosno prostor; stručni kadar, sportsku opremu. 
visoko rizičnih, tada bi trebalo razmisliti o uvođenju sistema odobrenja za osnivanje sportskih klubova, u kom slučaju bi i odredbe o uslovima učešća u organima dobile puni smisao.

U vezi sa navedenim uslovima, ZOS RS u čl. 33. st. 2. određuje da članovi uprave, uključujući i zastupnika i likvidacionog upravnika sportske organizacije, ne mogu biti: 1) osnivači, vlasnici udela ili akcija, zastupnici, likvidacioni upravnici, zaposleni ili članovi sportske organizacije koja se takmiči u istom rangu takmičenja; 2) članovi uprave i službena lica nadležnog sportskog saveza, odnosno službena lica organizacije u oblasti sporta koja upravlja sportskom ligom; 3) lice koje vrši javnu funkciju, kao ni lice koje vrši funkciju u organu političke stranke; 4) vlasnici i članovi organa sportskih kladionica, kao ni zaposleni u sportskoj kladionici; 5) sportski posrednici u odgovarajućoj grani sporta; 6) koja su osuđena za krivična dela protiv privrede, imovine i službene dužnosti, kao i za sledeća krivična dela: teško ubistvo, teška krađa, razbojnička krađa, razbojništvo, utaja, prevara, neosnovano korišćenje kredita i druge pogodnosti, iznuda, ucena i zelenaštvo, omogućavanje upotrebe doping sredstava, neovlašćena proizvodnja i stavljanje u promet doping sredstava, nasilničko ponašanje na sportskoj priredbi ili javnom skupu i dogovaranje ishoda takmičenja, dok traju pravne posledice osude; 7) koja ne mogu biti članovi organa privrednih društava ili udruženja u skladu sa zakonom kojim je uređen sukob interesa u obavljanju javnih dužnosti. ${ }^{34}$

3. Zabrana višestruke svojine u sportskim klubovima, odnosno zabrana članstva. - U cilju sprečavanja zloupotreba, uticaja na sportske rezultate na nedozvoljen način, sukoba interesa, dominacije pojedinačnog nad opštim interesom sportskog društva, ograničava se visina kapitala i broj društava u kojima neko može da ima kapital, krug lica koja mogu da budu vlasnici kapitala. ${ }^{35} \mathrm{U}$ vezi sa tim, ZOS RS (čl. 92. st. 11 - 15) sadrži nekoliko pravila. Prvim se precizira da isto lice ne može direktno, posredno ili preko povezanih lica biti vlasnik, odnosno imati udele ili akcije u više od jednog sportskog privrednog društva u istom stepenu takmičenja, a u okviru iste grane sporta može imati udele ili akcije na koje otpada najviše $5 \%$ osnovnog kapitala sportskog privrednog društva samo u još jednom sportskom privrednom društvu. Drugim se određuje da udele, odnosno akcije sportskog privrednog društva ne mogu, direktno, posredno ili preko povezanih lica da imaju lica čiji poslovi i aktivnosti mogu neposredno da utiču na takmičenje u odgovarajućoj grani sporta, odnosno stepenu takmičenja (sportske sudije, sportski posrednici, sportisti, treneri

34 Slična odreda se nalazi i u ZOŠ RH (čl. 38), s tom razlikom što se u njoj ne pominju neposredno lica navedena u tačkama 2. i 3. ZOS RS, što je drugačije određen krug organa u kojima određena lica ne mogu da učestvuju i što se određuje nadležni organ (Poverenstvo za profesionalne sportske klubove) koji sam ili na zahtev daje mišljenje da li su ispunjeni razlozi da neko ne može biti član određenih organa (uprave i nadzornog odbora). U ZOS CG (čl. 46) određen je znatno uži krug lica, koja se smatraju nepodobnim da uzmu učešće u stručnim i upravljačkim organima (pravosnažno osuđivana za krivična djela i prekršaje propisane posebnim propisima o sprečavanju nasilja i nedoličnog ponašanja na sportskim priredbama; pravosnažno osuđivana za krivična djela i prekršaje propisane ovim zakonom, a u vezi sa Međunarodnom konvencijom protiv dopinga u sportu; pravosnažno osuđivana za krivična djela protiv: života i tijela, sloboda i prava čovjeka i građanina, polne slobode, imovine, privrede, zdravlja ljudi, ustavnog uređenja bezbjednosti Crne Gore; članovi ili akcionari drugih sportskih klubova koji se takmiče u istom sportu).

35 Mićović, M., „Sportsko privredno društvo“, Zbornik PF u Splitu, br. 2/10, str. 282. 
i dr.), kao i vlasnici sportskih kladionica i zaposleni u sportskim kladionicama. Trećim se nameće obaveza otuđenja akcija, odnosno udela stečenih suprotno zakonu, a dok se to ne učini ne mogu se ostvarivati prava iz stečenih udela (akcija) ni u jednoj sportskoj organizaciji (do otuđenja udela, odnosno akcija, prava iz udela, odnosno akcija ostvaruje poverenik koga imenuje nadležni nacionalni granski sportski savez). Četvrtim se obavezuje lice koje ima udele (akcije) u društvu, a koje je izabrano ili imenovano na javnu funkciju ili na funkciju u organu političke stranke i dužno je da u roku od 30 dana od dana izbora ili imenovanja upravljačka prava po osnovu udela ili akcija prenese na pravno ili fizičko lice koje nije sa njim povezano lice, da ih ono, u svoje ime, a za račun funkcionera, vrši do prestanka javne funkcije, odnosno funkcije u organu političke stranke i da o ovom prenosu obavesti sportsko privredno društvo. Peto, sticanje udela (akcija) suprotno zakonu ništavo je. ${ }^{36}$

Stav o zabrani članstva, izložen kroz pravila ZOS-a RS, koji je motivisan potrebom da se zaštiti sportska etika i takmičenje (ako dve ekipe, u kojima jedno lice ima kapital, treba da se susretnu u šampionatu, povećava se rizik da se oni dogovore o ishodu, naročito kad je sportski rezultat od značaja samo za jedan od klubova $)^{37}$ bio je prihvaćen u nizu zemalja. ${ }^{38}$ Međutim, stav, kao i usvojena rešenja, ${ }^{39}$ su dovedeni u pitanje od strane Evropske komisije prema kojoj je to suprotno čl. 56 Ugovora o funkcionisanju EU, kojim se zabranjuju sva ograničenja u pogledu kretanja kapitala između država članica. ${ }^{40}$ Shodno tome, u Francuskoj se zabranjuje samo sticanje kontrole od strane nekog lica u više od jednog društva koje se bavi istom sportskom disciplinom. Naime, u čl. 122 - 7 ZOS-a Francuske zabranjuje se istom privatnopravnom licu: 1 . da kontroliše isključivo ili zajednički sa drugim

36 ZOS CG, za razliku od ZOS-a RS, prepoznaje prva dva pravila, s tim što su nešto drugačije formulisana (Član profesionalnog sportskog kluba ne može imati vlasničke udjele u drugom sportskom klubu koji se takmiči u istom sportu. A, lice koje obavlja djelatnost koja može da utiče na rezultat $u$ pojedinom sportu ne može sticati vlasničke udjele profesionalnih sportskih klubova koji se takmiče $u$ istom sportu posebno ako imaju u tom sportu svojstvo sportskog sudije, sportskog delegata, vlasnika ili člana uprave sportskih kladionica. ZOS RH, osim petog pravila, sadrži ista pravila, kao i ZOS RS, uz određene sadržinske razlike. Tako, određuje se da jedna osoba ne može imati dionice u više deoničkih društava istoga sporta u iznosu višem od $1 \%$ ukupnoga temeljnog kapitala u bilo kojem od tih društava (čl. 31. st. 2), s tim što u jednom društvu može imati deonice na koje otpada više od $25 \%$ temeljnoga kapitala društva samo uz saglasnost Poverenstva (čl. 32. st. 1). U slučaju značajnog učestvovanja u kapitalu društva (5\%), sticatelj mora bez odlganja, a najkasnije u roku od osam dana od dana sklapanja pravnog posla koji je osnova stjicanja, obavestiti Poverenstvo (čl. 33. st. 1). Iz svega navedenog može se zaključiti da ne postoje standardizovani stavovi u pogledu ograničenja (zabrane) članstva, da se rešenja razlikuju po stepenu restriktivnosti, pri čemu praksa pokazuje da što su rešenja restriktivnija to njihova primena dolazi do izražaja u malom broju slučajeva.

37 Amson, Ch., nav. delo, str. 27.

38 Pored napred navedenog, i Portugalija je 1997. godine usvojila pravilo prema kome se zabranjuje jednom sportskom društvu da drži deo kapitala drugog društva koje obavlja aktivnosti u istoj grani sporta. Ili, Śpanija, zakonom iz 1990. godine, je zabranila posedovanje akcija u procentu većem od $1 \%$ vrednosti kapitala, od strane istog lica, u više društava koja učestvuju u istom takmičenju. O tome: Amson, Ch., nav. delo, str. 28.

39 Ona su se temeljila na aktu koji je donela UEFA 19. maja 1998. godine, pod nazivom Integritet međuklupskog takmičenja, a kojim se zabranjuje jednoj osobi da vrši uticaj na vođenje sportskih aktivnosti više od jedne ekipe koja učestvuje u istom takmičenju. O tome: Buy, F. i dr., nav. delo, str. 276.

40 Isto, str. 271. 
licima nekoliko sportskih društava koja se bave istom sportskom disciplinom ili da ima značajan uticaj nad njima; ${ }^{41}$ 2. da bude direktor u više od jednog sportskog društva koja se bave istom sportskom disciplinom; 3 da kontroliše isključivo ili zajednički sa drugim licima jedno sportsko društvo ili da ima značajan uticaj nad njim i da bude direktor drugog sportskog društva koje se bavi istom sportskom disciplinom. Nepoštovanje ovih odredbi je kažnjivo sa $45.000 €$. Osim toga, osobi koja ostvaruje kontrolu zabranjeno je: 1. da odobrava zajam drugom sportskom društvu koje se bavi istom sportskom disciplinom; 2 da se pojavi kao jemac takvog sportskog društva ili da ponudi neki oblik obezbeđenja. Svaki pojedinac, predsednik ili direktor pravnog lica koji krši navedena pravila, kazniće se novčanom kaznom od 45.000 evra i zatvorskom kaznom u trajanju od godinu dana (čl. 122-9 ZOS-a).

4. Raspodela neto dobiti. - U cilju unapređenja sportske aktivnosti, sportska društva imaju obavezu da određeni procenat neto dobiti unesu u posebne rezerve. U vezi sa tim u ZOS-u RS je određeno da se najmanje $70 \%$ mora reinvestirati u sportsku delatnost društva (čl. 92. st. 4). U ZOS-u RH je određeno da se u posebne zakonske rezerve društva mora uneti najmanje polovina neto dobiti koja preostane nakon što se podmire gubici iz ranijih godina i zakonske rezerve (čl. 37. st. 3). Ako se ima u vidu napred navedena francuska rešenja i praksa, čini se da pitanje raspodele dobiti, nakon što se podmire obaveze koje klub ima, na osnovu zakona kao privredno društvo, treba ostaviti na volju onima koji investiraju kapital u sport.

5) Nadzor nad radom klubova. - Pravila o nadzoru su posebno normirana u ZOS-u RH, u skladu sa pravilima o postojanju posebnog stručnog tela (Poverenstvo za profesionalne sportske klubove) koje je osnovano radi praćenja obavljanja delatnosti profesionalnih sportskih klubova. Tako, normirana je obveza društva da Poverenstvu redovno, bez odlaganja, šalje obaveštenja o svim važnijim poslovnim događajima, a naročito o ugovorima koje društvo sklapa sa članovima uprave i nadzornog odbora, osim ugovora o obavljanju poslova članova uprave odnosno nadzornog odbora, ugovorima koje društvo sklapa sa stokholderima koji drže najmanje $5 \%$ akcija, ugovorima koje društvo sklapa s drugim osobama čije delovanje može imati uticaj na obavljanje delatnosti istog. Jednom godišnje profesionalni sportski klub je obavezan Poverenstvu podnositi: račun dobiti i gubitka, izveštaj o registrovanim sportistima seniorske ekipe, izveštaj o članovima kluba i članovima tela kluba, plan poslovanja u idućoj poslovnoj godini, godišnji finansijski izveštaj i revizorski izveštaj. U skladu sa opštim pravilima o informisanju javnosti o okolnostima koje bitno utiču na učešće u upravljanju društvom, lice koje je steklo kvalifikovano učešće u kapitalu društva dužno je da o tome obavesti Poverenstvo. U suprotnom, ne može ostvarivati prava koja mu pripadaju po osnovu akcija koje poseduje. I na kraju, u kontekstu zakonske obveze sprovođenja revizije poslovanja, profesionalni sportski klubovi su dužni u roku od dva meseca od dana dostave rešenja o upisu u

41 Smatra se da postoji značajan uticaj ako to lice ima barem 20 \% glasova. O tome: Simon, G. i dr., nav. delo, str. 166 . 
Registar obaviti reviziju koja se sprovodi u skladu s odredbama Zakona o reviziji. Prethodno su obvezni zatražiti saglasnost Poverenstva na izbor revizora. ${ }^{42}$

6. Državna pomoć (subvencije) klubovima. - Prema rešenju usvojenom u ZOS-u Francuske, profesionalni klubovi mogu da prime subvencije na osnovu sporazuma zaključenog sa lokalnom zajednicom. Iznos subvencije, koje se daju u funkciji zadovoljenja javnog interesa, ne može da pređe 2,3 miliona evra po sezoni. Zahtev za subvenciju treba da bude propraćen obrazloženjem o korišćenju sredstva, uz eventualni izveštaj o tome u koje svrhe su iskorišćena ranije odobrena sredstva. Pored subvencija za postizanje javnog interesa, mogu se odobriti i one koje ne služe ostvarenju tog interesa, ali u iznosu koji ne može da pređe 1,6 miliona evra. ${ }^{43}$

\section{ZAKLJUČAK}

Na zakonodavnom planu, uobičajeno je da se u prvi plan stavljaju organizacioni oblici preko kojih sportske organizacije mogu da obavljaju svoje aktivnosti, udruženja i društva, a ne same sportske organizacije, među kojima se izdvajaju sportski klubovi, koji mogu da imaju amaterski ili profesionalni status. Obrnut pristup bi omogućio da konačno započne proces jasnog odvajanja profesionalnih od amaterskih klubova (a ne kao što je danas slučaj da se niz pravila jednako ili gotovo jednako primenjuje i na amaterske i na profesionalne klubove), postavljanje jasnih kriterijuma kada neki klub mora da ima profesionalni status, u obliku privrednog društva i u odgovarajućoj formi. U vezi sa tim, kao mogući putokaz mogla bi da posluže rešenja koja su prihvaćena u Francuskoj.

Prilikom definisanja okvira za osnivanje i rad profesionalnih sportskih klubova svakako treba izbegavati restriktivna rešenja u odnosu na ona koja se primenjuju generalno na privredna društva, naročito ona koja se tiču isplate neto dobiti. Bez toga, neće biti sportskih investicija, a proces profesionalizacije će teći usporeno. Osim toga, jasno je da se pravila o zabrani ulaganja kapitala u više od jednog društva moraju transformisati u pravila o zabrani kantrole više društava. 6 .

42 O tome: Jelušić, D., „Sportsko dioničko društvo“, Informator, br. 6310-6311 od 27. VIII. 2014., str.

43 Amson, Ch., nav. delo, str. 30. 


\section{PROFESSIONAL SPORTS CLUB}

With regard to the organization of professional clubs, two models can be applied. According to the first model, clubs have the freedom to choose the organizational form (association or commercial company) in which sports activities will be carried out. Second model imposes the requirement for the clubs to be organized in the form of commercial company, in one of the corporation forms, provided that it can be also specialized sports form. To the establishment and operation of sports associations, as sui generis commercial companies, apply more specific rules concerning: the conditions for the establishment of clubs; conditions for participation in professional and management bodies; prohibiting multiple ownership of sports clubs, i.e., prohibition of membership; allocation of net profit; control over the work of clubs; state aid (subsidies) for the clubs.

Key words: sports club, commercial company, association, form, sports activity 